\title{
Slurry Mix Evaporator Batch Acceptability and Test Cases of the Product Composition Control System with Thorium as a Reportable Element
}

T. B. Edwards

September 2010

Savannah River National Laboratory Savannah River Nuclear Solutions, LLC Aiken, SC 29808

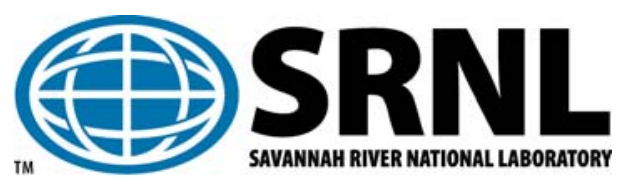


SRNL-STI-2010-00557

Revision 0

\section{DISCLAIMER}

This work was prepared under an agreement with and funded by the U.S. Government. Neither the U.S. Government or its employees, nor any of its contractors, subcontractors or their employees, makes any express or implied:

1. warranty or assumes any legal liability for the accuracy, completeness, or for the use or results of such use of any information, product, or process disclosed; or

2. representation that such use or results of such use would not infringe privately owned rights; or

3. endorsement or recommendation of any specifically identified commercial product, process, or service.

Any views and opinions of authors expressed in this work do not necessarily state or reflect those of the United States Government, or its contractors, or subcontractors.

\section{Printed in the United States of America \\ Prepared for \\ U.S. Department of Energy}




\section{REVIEWS AND APPROVALS}

\section{AUTHORS:}

T. B. Edwards, Applied Computational Engineering and Statistics

Date

TECHNICAL REVIEW:

E. P. Shine, Applied Computational Engineering and Statistics

Date

D. K. Peeler, Process Technology Programs

Date

APPROVAL:

P. L. Lee, Manager

Date

Applied Computational Engineering and Statistics

C. C. Herman, Manager

Date

Process Technology Programs

J. E. Occhipinti, Manager

Date

Waste Solidification Engineering 


\section{EXECUTIVE SUMMARY}

The Defense Waste Processing Facility (DWPF), which is operated by Savannah River Remediation, LLC (SRR), has recently begun processing Sludge Batch 6 (SB6) by combining it with Frit 418 at a nominal waste loading (WL) of 36\%. A unique feature of the SB6/Frit 418 glass system, as compared to the previous glass systems processed in DWPF, is that thorium will be a reportable element for the resulting wasteform. Several activities were initiated based upon this unique aspect of SB6 including an investigation regarding the handling of thorium in the acceptability process at the Slurry Mix Evaporator (SME) hold-point for DWPF operations.

The conclusions provided in this report are that no changes need to be made to the SME acceptability process (i.e., no modifications to WSRC-TR-95-00364, Revision 5, are needed) and no changes need to be made to the Product Composition Control System (PCCS) itself (i.e. the spreadsheet utilized by Waste Solidification Engineering (WSE) for acceptability decisions does not require modification) in response to thorium becoming a reportable element for DWPF operations.

In addition, the inputs and results for the two test cases requested by WSE for use in confirming the successful activation of thorium as a reportable element for DWPF operations during the processing of SB6 are presented in this report. 


\section{TABLE OF CONTENTS}

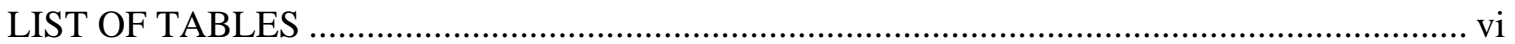

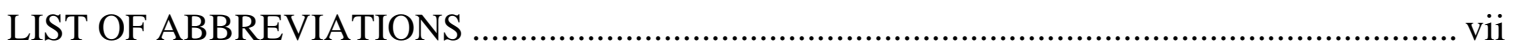

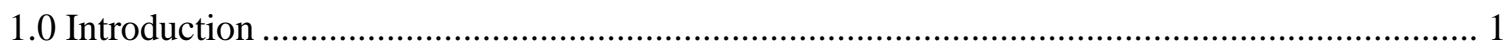

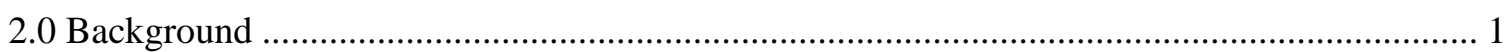

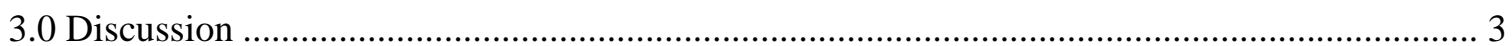

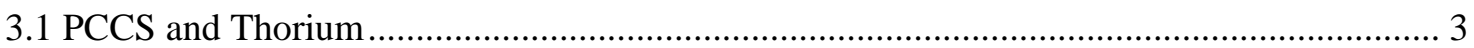

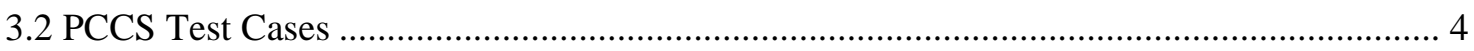

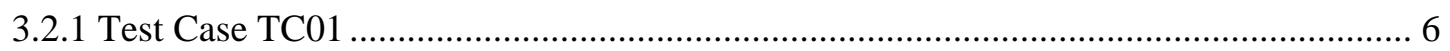

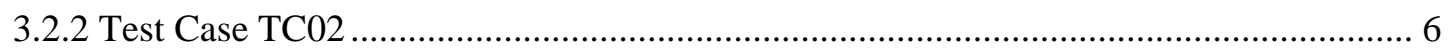

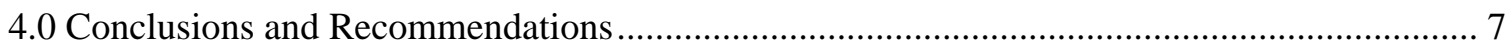

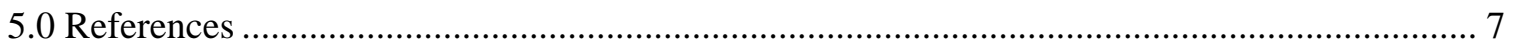

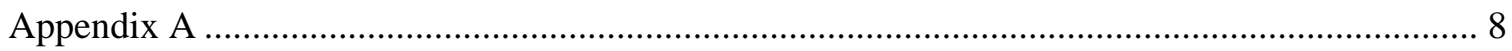

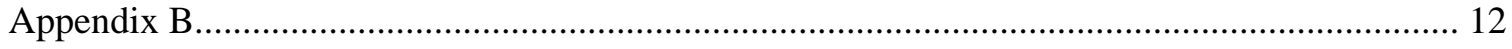

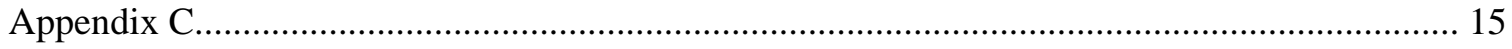




\section{LIST OF TABLES}

Table 1. PCCS Test Cases for Verification of Thorium Activation............................................ 4

Table 2. Constraint Vectors and PAR Limits (Offsets, $\beta$ 's) for All Constraints Except Liquidus

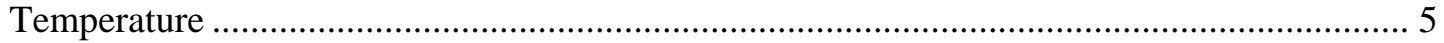




\section{LIST OF ABBREVIATIONS}

$\begin{array}{ll}\text { DWPF } & \text { Defense Waste Processing Facility } \\ \text { EPAR } & \text { Expected Property Acceptable Region } \\ \text { MAR } & \text { Measurement Acceptability Region } \\ \text { PAR } & \text { Property Acceptability Region } \\ \text { PCCS } & \text { Product Composition Control System } \\ \text { SB6 } & \text { Sludge Batch 6 } \\ \text { SME } & \text { Slurry Mix Evaporator } \\ \text { SRAT } & \text { Sludge Receipt and Adjustment Tank } \\ \text { SRNL } & \text { Savannah River National Laboratory } \\ \text { SRR } & \text { Savannah River Remediation } \\ \text { TC01 } & \text { Test Case 1 (also TC01a and TC01b) } \\ \text { TC02 } & \text { Test Case 2 } \\ \text { TTR } & \text { Technical Task Request } \\ \text { TT\&QA } & \text { Task Technical and Quality Assurance } \\ T_{L} & \text { Liquidus Temperature } \\ \text { WL } & \text { Waste Loading } \\ \text { WSE } & \text { Waste Solidification Engineering } \\ \text { wt\% } & \text { weight percent } \\ \Delta G_{p} & \text { An estimate of the free energy of hydration of a glass in kcal/mole } \\ & \text { derived from the composition of the glass. }\end{array}$




\subsection{Introduction}

The Defense Waste Processing Facility (DWPF), which is operated by Savannah River Remediation, LLC (SRR), has recently begun processing Sludge Batch 6 (SB6) by combining it with Frit 418 at a nominal waste loading (WL) of 36\%. A unique feature of the SB6/Frit 418 glass system, as compared to the previous glass systems processed in DWPF, is that thorium will be a reportable element (i.e., concentrations of elemental thorium in the final glass product greater than 0.5 weight percent $(\mathrm{wt} \%)$ ) for the resulting wasteform. Several activities were initiated based upon this unique aspect of SB6. One of these was an investigation into the impact of thorium on the models utilized in DWPF's Product Composition and Control System (PCCS). While the PCCS is described in more detail below, for now note that it is utilized by Waste Solidification Engineering (WSE) to evaluate the acceptability of each batch of material in the Slurry Mix Evaporator (SME) before this material is passed on to the melter. The evaluation employs models that predict properties associated with processability and product quality from the composition of vitrified samples of the SME material. The investigation of the impact of thorium on these models was conducted by Peeler and Edwards [1] and led to a recommendation that DWPF can process the SB6/Frit 418 glass system with $\mathrm{ThO}_{2}$ concentrations up to $1.8 \mathrm{wt} \%$ in glass. Questions also arose regarding the handling of thorium in the SME batch acceptability process as documented by Brown, Postles, and Edwards [2]. Specifically, that document is the technical bases of PCCS, and while Peeler and Edwards confirmed the reliability of the models, there is a need to confirm that the current implementation of DWPF's PCCS appropriately handles thorium as a reportable element. Realization of this need led to a Technical Task Request (TTR) prepared by Bricker [3] that identified some specific SME-related activities that the Savannah River National Laboratory (SRNL) was requested to conduct. SRNL issued a Task Technical and Quality Assurance (TT\&QA) plan [4] in response to the SRR request. The activities defined in the TT\&QA plan that are addressed in this report are:

(1) Reviewing the current version of "SME Acceptability Determination for DWPF Process Control," WSRC-TR-95-00364, Revision 5, to assess if there is a need to update the technical basis for DWPF's PCCS to address the introduction of thorium as a reportable element and to complete this update, if needed, and

(2) Developing and documenting evaluations of PCCS test case scenarios that were provided to SRNL by WSE of SRR [5]. These test cases are to be utilized by WSE to confirm the successful implementation of the steps necessary to activate thorium as part of the input to PCCS.

WSE made an additional request to SRNL via electronic mail (see [4]). SRNL was requested to generate a white paper providing a statistical method for estimating thorium concentrations based on the established analysis of iron. This request has been rescinded by WSE via electronic mail (see Appendix C).

\subsection{Background}

While the SME acceptability process is fully described by Brown, Postles, and Edwards [2], an overview of its underlying philosophy is provided in this section. A decision on the acceptability of the waste glass product cannot be made at the melter or after it has been produced, since by then no further changes to the composition of the material are possible. Therefore, the 
acceptability decision is made on the upstream process, rather than on the downstream melt or glass product. That is, it is based on statistical process control rather than statistical quality control, and the acceptability decision is made at the SME. The SME is uniquely positioned in the process - it is both the first control point in the process wherein all necessary constituents are present and the last control point at which any change to these constituents can be effected. Thus, the control strategy involves monitoring the blended SME batch.

The monitoring of the SME is accomplished by sampling its contents. For each SME batch, a set of $(n \geq 4)$ samples is taken to initiate an acceptability decision. Each of these samples is vitrified and the chemical compositions of the resulting $n$ glasses are measured. The average of the measured chemical compositions for a minimum of 4 samples is determined, and this average composition serves as the basis for the acceptability decision for the SME batch.

However, the average chemical composition, while necessary, is not sufficient in and of itself, to complete the assessment of the performance of the SME contents against the constraints. Some of the constraints involve properties (either process or product quality) such as viscosity, liquidus temperature, and durability. These properties cannot be measured in situ, and thus, they must be predicted from models that relate these properties to glass composition. Not only must the model predictions satisfy their corresponding property constraints, but the constraints must also be appropriately met after the applicable modeling uncertainties are introduced into the acceptability decision.

For the constraints involving property-composition models and for most of the other constraints that directly involve composition, the uncertainties associated with the SME samples must also be accounted for as part of the acceptability decision. The uncertainties, labeled measurement uncertainties in this report, include those related to the collection of the slurry samples in the $\mathrm{SME}$, the preparation of these samples for measurement, and the measurements themselves.

A glass composition representing the "average" content of a SME batch is deemed to be within the acceptable operating window for the DWPF if all of the applicable constraints are satisfied, at appropriate confidence levels, after all of the related property modeling and measurement uncertainties are accounted for. Conceptually, there is a layered approach to the acceptability decision. At the first step, the question is, does the average chemical composition representing the SME contents directly or through model predictions satisfy the constraints? If the answer is yes, the composition is said to be within the Expected Property Acceptable Region (EPAR). However, the EPAR does not account for uncertainties in the predicting models. If, after the property model uncertainties are accounted for (to be discussed later), the chemical composition still meets the constraints, then the composition is said to be within the Property Acceptable Region (PAR). Finally, if, after measurement uncertainties are accounted for (to be discussed later), the chemical composition still meets the constraints, then the composition is said to be within the Measurement Acceptable Region (MAR). A composition that is within the MAR for each of the applicable constraints is said to be within the acceptable operating window of the DWPF.

Some additional comments regarding the control strategy are warranted. As mentioned earlier, some of the constraints are directly related to composition and do not involve model predictions. For these constraints there would be fewer layers in the above description that would be applicable. Specifically, the PAR limits would be the same as the EPAR limits for such constraints since there is no property model uncertainty. In a similar fashion, if there is no need to apply property modeling or measurement uncertainties for a given constraint (which is true for a pair of constraints related to the reliability of the chemical composition measurement themselves), then the EPAR limit equals the PAR limit equals the MAR limit for that constraint. Finally, the 
DWPF control strategy has evolved over the course of radioactive operations. Revisions to the strategy have introduced alternatives for satisfying some of the constraints as well as a new property-composition model for liquidus temperature and a constraint associated with the formation of a nepheline crystalline phase under certain heat treatments.

\subsection{Discussion}

The SME acceptability process, whose overview is described in the previous section, is implemented in DWPF's PCCS. In this section, the two topics of concern to this investigation that were outlined above regarding the introduction of thorium as a reportable element for DWPF are addressed. In Section 3.1, the current implementation of PCCS is investigated to confirm that if measurements for thorium are passed to that system they will be appropriately incorporated into the SME acceptability process, and in Section 3.2, the results, i.e., anticipated PCCS output, for two test cases described by Bricker and Ray [5] are presented. The second set of results provides WSE with a basis for validating the successful activation of thorium in the macros that link the measurements generated by the DWPF Laboratory to the inputs to PCCS. That is, in Section 3.2 values that represent the PCCS output for a given set of input values are given for the two test cases provided by Bricker and Ray [5].

\subsection{PCCS and Thorium}

To investigate how thorium is currently handled by PCCS, one may appeal to the most recent revision of the SME acceptability process as documented by Brown, Postles, and Edwards [2]. A review of that document clearly shows that $\mathrm{ThO}_{2}$ is included in the list of oxides that is utilized to represent the composition of the vitrified SME material. That is, while thorium was not a reportable element for any of the previous glass systems processed at DWPF, there has been a "placeholder" for this element in PCCS since that system was created. For more details, the reader is referred to the discussion on the chemical composition measurements of SME samples in Appendix A of reference [2] and Tables A1-A3 in that appendix. $\mathrm{ThO}_{2}$ is one of the oxides listed as a compositional component of the SME samples in the discussion of that appendix and in the tables indicated. Thus, when PCCS was created, a measured thorium concentration was anticipated as an input that would be needed (sooner or later) to represent the compositional information for SME samples. The processing of SB6 is the realization of that necessity.

In establishing macros that were utilized to link the DWPF Laboratory measurements to the inputs to PCCS, WSE was able to simplify their systems by leaving as null entries the thorium measurements for the SME sample results. PCCS took these entries as zeros (i.e., indicating that there was no reportable thorium in that SME material) in the subsequent calculations supporting the acceptability decision for that SME batch. If positive values are entered into PCCS to represent the thorium concentrations in a set of SME samples, they will be appropriately handled in the subsequent calculations and will be correctly incorporated in the SME acceptability process. Thus, no changes need to be made to the SME acceptability process (i.e., reference [2] does not require a revision) and no changes need to be made to PCCS itself (i.e. the spreadsheet utilized by WSE for acceptability decisions does not require modification) in response to thorium becoming a reportable element for DWPF operations.

One other aspect of how thorium is handled in PCCS is worth mentioning as part of this discussion, and that is with regard to uncertainty, specifically compositional measurement uncertainty. Please note that the entries for measurement uncertainty for thorium as indicated in Tables B1 through B3 of Appendix B in reference [2] are all zero. This is a consequence of how uncertainties were originally determined: based upon DWPF Laboratory measurements of simulants analyzed as part of the qualification of DWPF for radioactive operations. Since 
thorium (a radioactive element) was not present during this testing, its uncertainty information was set to zero in PCCS as was the uncertainty information for uranium (another radioactive component) obviously not included in the DWPF simulant.

\subsection{PCCS Test Cases}

In this section, the results, i.e., anticipated PCCS output, for two test cases described by Bricker and Ray [5] are presented. These results provide WSE with a basis for validating the successful activation of thorium in the macros that link the measurements generated by the DWPF Laboratory to the inputs to PCCS. That is, in this section, values that represent the PCCS output for a given set of input values are given for the two test cases provided by Bricker and Ray [5]. Table 1 provides the two test cases from [5] that are to be addressed in this section.

Table 1. PCCS Test Cases for Verification of Thorium Activation.

\begin{tabular}{|c|c|}
\hline $\begin{array}{c}\text { Test Case (TC) } \\
\text { Number }\end{array}$ & $\begin{array}{c}\text { Description of } \\
\text { Test Case }\end{array}$ \\
\hline TC01 & $\begin{array}{c}\text { PCCS constraints (at a minimum, derived values) are equivalent for a } \\
\text { specified composition (excluding thorium) before and after activation. }\end{array}$ \\
\hline TC02 & $\begin{array}{c}\text { PCCS constraints (at a minimum, derived values) for B, Li, and Na } \\
\text { leaching; and sum of oxides for a specified composition (including } \\
\text { thorium) match results anticipated from models after activation. }\end{array}$ \\
\hline
\end{tabular}

The intent of test case TC01 is to show that activating thorium as a zero entry in the link between the measurements from the DWPF Laboratory and the inputs to PCCS introduces no changes to the output from the PCCS calculations without this zero entry. The intent of test case TC02 is to demonstrate that once a positive value for the concentration of thorium is entered into PCCS the constraints whose evaluations depend on thorium are appropriately modified. As indicated in the description of TC02, the only constraints that should be affected are the durability constraints (i.e., those associated with the predicted leaching of boron, lithium, and sodium) and the sum of oxides constraints. These are the only constraints that should change. This is seen by a review of the information in Table 6-12 and Table 8-3 of reference [2].

Table 6-12 of reference [2] shows that thorium does not influence the outcome of the predictions of the PCCS liquidus temperature $\left(\mathrm{T}_{\mathrm{L}}\right)$ model, and thus, thorium does not affect the outcome of the $\mathrm{T}_{\mathrm{L}}$ constraint. Table 8-3 in reference [2] provides the coefficients for the other PCCS constraints. That table is reproduced in this report as Table 2 and the row of coefficients associated with thorium is highlighted to clearly show those constraints that are affected by thorium. Those are the constraints with nonzero entries in the highlighted row; that is, the constraints associated with $\mathrm{B}, \mathrm{Li}$, and $\mathrm{Na}$ leaching (the durability model constraints) and the constraints associated with "Low Conserv" and "High Conserv" (the conservation of mass or sum of oxides constraints).

Each test case developed in this section consists of four values for each analyte of interest. These four values represent measurements of that analyte from four (hypothetical) samples - the minimum number allowable by PCCS. 
Table 2. Constraint Vectors and PAR Limits (Offsets, $\beta$ 's) for All Constraints Except Liquidus Temperature

\begin{tabular}{|c|c|c|c|c|c|c|c|c|c|c|c|c|c|c|c|c|c|c|c|}
\hline & $\mathrm{B}$ & \begin{tabular}{|l|}
$\mathrm{Li}$ \\
\end{tabular} & \begin{tabular}{|l|}
$\mathrm{Na}$ \\
\end{tabular} & High & Low & & & Low & High & Low & High & & & & & & & & \\
\hline Oxide & Leaching & Leaching & Leaching & \begin{tabular}{|l|l} 
Viscosity \\
\end{tabular} & Viscosity & Homogeneity & $\mathrm{Al}_{2} \mathrm{O}_{3}$ & Conserv & \begin{tabular}{|l|l|} 
Conserv \\
\end{tabular} & Frit & Frit & $\mathrm{TiO}_{2}$ & $\mathrm{NaCl}$ & $\mathrm{NaF}$ & $\mathrm{Cr}_{2} \mathrm{O}_{3}$ & $\mathrm{Na}_{2} \mathrm{SO}_{4}$ & $\mathrm{Cu}$ & $\mathrm{R}_{2} \mathrm{O}$ & Neph \\
\hline $\mathrm{Al}_{2} \mathrm{O}_{3}$ & 37.680 & 37.680 & \begin{tabular}{|l|l|}
37.680 \\
\end{tabular} & -2 & 2 & 575.8565 & 101.961 & 101.961 & \begin{tabular}{|l|l|}
-101.9612 \\
\end{tabular} & 0 & 0 & 0 & 0 & 0 & 0 & 0 & 0 & 0 & \begin{tabular}{|l|}
-63.2159 \\
\end{tabular} \\
\hline $\mathrm{B}_{2} \mathrm{O}_{3}$ & -10.430 & -10.430 & -10.430 & 1 & -1 & 111.6360 & \begin{tabular}{|l|}
0 \\
\end{tabular} & 69.620 & \begin{tabular}{|l|}
-69.6202 \\
\end{tabular} & \begin{tabular}{|l|}
69.6202 \\
\end{tabular} & -69.6202 & 0 & 0 & 0 & 0 & 0 & 0 & 0 & \begin{tabular}{|l|}
0 \\
\end{tabular} \\
\hline $\mathrm{BaO}$ & -23.180 & -23.180 & -23.180 & 0 & 0 & 0 & 0 & 153.339 & \begin{tabular}{|l|}
-153.3394 \\
\end{tabular} & \begin{tabular}{|l|}
0 \\
\end{tabular} & \begin{tabular}{|l|}
0 \\
\end{tabular} & 0 & 0 & 0 & 0 & 0 & 0 & 0 & 0 \\
\hline $\mathrm{HCOO}$ & 0.000 & 0.000 & 0.000 & 0 & 0 & 0 & 0 & \begin{tabular}{|l|}
0.000 \\
\end{tabular} & \begin{tabular}{|l|}
0.0000 \\
\end{tabular} & 0 & 0 & 0 & 0 & 0 & 0 & 0 & 0 & 0 & 0 \\
\hline $\begin{array}{ll}\mathrm{CaO} \\
\end{array}$ & -13.790 & -13.790 & -13.790 & 0 & 0 & 316.7253 & 0 & \begin{tabular}{|l|}
56.079 \\
\end{tabular} & \begin{tabular}{|l|}
-56.0794 \\
\end{tabular} & 0 & 0 & 0 & 0 & 0 & 0 & 0 & 0 & 0 & 0 \\
\hline $\mathrm{Ce}_{2} \mathrm{O}_{3}$ & -44.990 & -44.990 & -44.990 & 0 & 0 & 1853.8236 & 0 & \begin{tabular}{|l|}
328.238 \\
\end{tabular} & -328.2382 & 0 & 0 & 0 & 0 & 0 & 0 & 0 & 0 & 0 & 0 \\
\hline $\begin{array}{ll}\mathrm{NaCl} \\
\end{array}$ & 0.000 & 0.000 & 0.000 & 0 & 0 & 0 & 0 & \begin{tabular}{|l|}
0.000 \\
\end{tabular} & \begin{tabular}{|l|}
0.0000 \\
\end{tabular} & 0 & 0 & 0 & -58.4428 & 0 & 0 & 0 & 0 & 0 & 0 \\
\hline $\mathrm{Cr}_{2} \mathrm{O}_{3}$ & 11.950 & 11.950 & 11.950 & 0 & 0 & 0 & 0 & 151.990 & \begin{tabular}{|l|}
-151.9902 \\
\end{tabular} & \begin{tabular}{ll|}
0 \\
\end{tabular} & 0 & 0 & 0 & 0 & -151.9902 & 0 & 0 & 0 & 0 \\
\hline $\mathrm{Cs}_{2} \mathrm{O}$ & -80.380 & -80.380 & -80.380 & 2 & -2 & 451.8814 & 0 & 281.809 & \begin{tabular}{|l|}
-281.8094 \\
\end{tabular} & 281.8094 & -281.8094 & 0 & 0 & 0 & \begin{tabular}{|l|}
0 \\
\end{tabular} & 0 & 0 & -281.8094 & 0 \\
\hline $\mathrm{CuO}$ & -4.955 & -4.955 & -4.955 & 0 & 0 & 0 & 0 & \begin{tabular}{|l|}
75.544 \\
\end{tabular} & \begin{tabular}{|l|}
-75.5439 \\
\end{tabular} & \begin{tabular}{|l|}
0 \\
\end{tabular} & \begin{tabular}{|l|}
0 \\
\end{tabular} & 0 & 0 & 0 & 0 & 0 & -63.5383 & \begin{tabular}{|l|}
0 \\
\end{tabular} & 0 \\
\hline $\mathrm{NaF}$ & 0.000 & 0.000 & 0.0000 & 0 & 0 & 0 & 0 & 0.000 & \begin{tabular}{|l|}
0.0000 \\
\end{tabular} & 0 & 0 & 0 & 0 & -41.9882 & 0 & 0 & \begin{tabular}{|l|}
0 \\
\end{tabular} & 0 & 0 \\
\hline $\mathrm{Fe}_{2} \mathrm{O}_{3}$ & 14.560 & 14.560 & 14.560 & 2 & -2 & 901.9096 & 0 & 159.692 & -159.6922 & 0 & 0 & 0 & 0 & 0 & 0 & 0 & 0 & 0 & 0 \\
\hline $\mathrm{K}_{2} \mathrm{O}$ & -76.410 & -76.410 & -76.410 & 2 & -2 & 151.0552 & 0 & \begin{tabular}{|l|}
94.203 \\
\end{tabular} & \begin{tabular}{|l|}
-94.2034 \\
\end{tabular} & \begin{tabular}{|l|}
94.2034 \\
\end{tabular} & \begin{tabular}{|l|}
-94.2034 \\
\end{tabular} & 0 & 0 & 0 & 0 & 0 & 0 & -94.2034 & 0 \\
\hline $\mathrm{La}_{2} \mathrm{O}_{3}$ & -48.590 & -48.590 & -48.590 & 0 & 0 & 1840.1560 & 0 & \begin{tabular}{|l|}
325.818 \\
\end{tabular} & -325.8182 & \begin{tabular}{|l|}
0 \\
\end{tabular} & 0 & 0 & 0 & 0 & 0 & 0 & 0 & 0 & 0 \\
\hline $\mathrm{Li}_{2} \mathrm{O}$ & \begin{tabular}{|l|}
-24.040 \\
\end{tabular} & -24.040 & -24.040 & 2 & -2 & $\begin{array}{l}47.9084 \\
\end{array}$ & 0 & \begin{tabular}{|l|}
29.877 \\
\end{tabular} & \begin{tabular}{|l|}
-29.8774 \\
\end{tabular} & \begin{tabular}{|l|}
29.8774 \\
\end{tabular} & -29.8774 & 0 & 0 & 0 & 0 & 0 & 0 & -29.8774 & 0 \\
\hline $\mathrm{MgO}$ & -6.570 & -6.570 & -6.570 & 0 & 0 & 0 & 0 & 40.311 & \begin{tabular}{|l|}
-40.3114 \\
\end{tabular} & \begin{tabular}{|l|}
0 \\
\end{tabular} & 0 & 0 & 0 & 0 & 0 & 0 & 0 & 0 & 0 \\
\hline $\mathrm{MnO}$ & -24.440 & -24.440 & -24.440 & 0 & 0 & 0 & 0 & 70.937 & \begin{tabular}{|l|}
-70.9374 \\
\end{tabular} & 0 & 0 & 0 & 0 & 0 & 0 & 0 & 0 & 0 & 0 \\
\hline $\mathrm{MoO}_{3}$ & 16.460 & 16.460 & 16.460 & 0 & 0 & 812.9341 & 0 & 143.938 & -143.9382 & 0 & 0 & 0 & 0 & 0 & 0 & 0 & 0 & 0 & 0 \\
\hline $\mathrm{NO}_{2}$ & 0.000 & 0.000 & 0.000 & 0 & 0 & 0 & 0 & 0.000 & \begin{tabular}{|l|}
0.0000 \\
\end{tabular} & 0 & 0 & 0 & 0 & 0 & 0 & 0 & 0 & 0 & 0 \\
\hline $\mathrm{NO}_{3}$ & 0.000 & 0.000 & 0.000 & 0 & 0 & 0 & 0 & 0.000 & 0.0000 & 0 & 0 & 0 & 0 & 0 & 0 & 0 & 0 & 0 & 0 \\
\hline $\mathrm{Na}_{2} \mathrm{O}$ & -53.090 & -53.090 & -53.090 & 2 & -2 & 99.3833 & 0 & 61.979 & \begin{tabular}{|l|}
-61.9790 \\
\end{tabular} & \begin{tabular}{|l|l|}
61.9790 \\
\end{tabular} & -61.9790 & 0 & 0 & 0 & 0 & 0 & 0 & -61.9790 & \begin{tabular}{|l|}
-38.4270 \\
\end{tabular} \\
\hline $\mathrm{Na}_{2} \mathrm{SO}_{4}$ & 0.000 & 0.000 & 0.000 & 0 & 0 & 0 & 0 & 0.000 & \begin{tabular}{|l|}
0.0000 \\
\end{tabular} & \begin{tabular}{|l|}
0 \\
\end{tabular} & $\begin{array}{l}0 \\
\end{array}$ & 0 & 0 & 0 & 0 & -142.0412 & 0 & 0 & \begin{tabular}{|l|}
0 \\
\end{tabular} \\
\hline $\mathrm{Nd}_{2} \mathrm{O}_{3}$ & -37.790 & -37.790 & -37.790 & 0 & 0 & 1900.3616 & 0 & 336.478 & \begin{tabular}{|l|}
-336.4782 \\
\end{tabular} & 0 & 0 & 0 & 0 & 0 & 0 & \begin{tabular}{|l|}
0 \\
\end{tabular} & 0 & 0 & 0 \\
\hline $\mathrm{NiO}$ & \begin{tabular}{|l|}
0.370 \\
\end{tabular} & \begin{tabular}{|l|}
0.370 \\
\end{tabular} & 0.370 & 0 & 0 & $\begin{array}{l}0 \\
\end{array}$ & 0 & \begin{tabular}{|l|}
74.7099 \\
\end{tabular} & \begin{tabular}{|l|}
-74.7094 \\
\end{tabular} & 0 & 0 & 0 & 0 & 0 & 0 & 0 & 0 & 0 & 0 \\
\hline $\mathrm{P}_{2} \mathrm{O}_{5}$ & -26.550 & -26.550 & -26.55 & 0 & 0 & 0 & 0 & 141.945 & -141.9446 & 0 & 0 & 0 & 0 & 0 & 0 & 0 & 0 & 0 & 0 \\
\hline $\mathrm{PbO}$ & 21.050 & 21.050 & 21.050 & \begin{tabular}{|l|}
0 \\
\end{tabular} & $\begin{array}{l}0 \\
\end{array}$ & 0 & 0 & 223.189 & \begin{tabular}{|l|}
-223.1894 \\
\end{tabular} & \begin{tabular}{|l|}
0 \\
\end{tabular} & 0 & 0 & 0 & 0 & 0 & 0 & 0 & 0 & 0 \\
\hline $\mathrm{SiO}_{2}$ & 4.050 & 4.050 & 4.050 & \begin{tabular}{|l|l|}
-0.78734 \\
\end{tabular} & 1.19412 & 96.3460 & 0 & \begin{tabular}{|l|}
60.085 \\
\end{tabular} & \begin{tabular}{|l|}
-60.0848 \\
\end{tabular} & \begin{tabular}{|l|}
60.0848 \\
\end{tabular} & -60.0848 & 0 & 0 & 0 & 0 & 0 & 0 & 0 & \begin{tabular}{|l|}
22.8322 \\
\end{tabular} \\
\hline $\mathrm{ThO}_{2}$ & 19.230 & 19.230 & 19.230 & \begin{tabular}{|l|}
0 \\
\end{tabular} & 0 & 0 & 0 & 264.037 & -264.0368 & \begin{tabular}{|l|}
0 \\
\end{tabular} & \begin{tabular}{|l|}
0 \\
\end{tabular} & 0 & 0 & 0 & 0 & 0 & 0 & 0 & 0 \\
\hline $\mathrm{TiO}_{2}$ & 16.270 & 16.270 & 16.270 & 0 & 0 & 0 & 0 & \begin{tabular}{|l|}
79.899 \\
\end{tabular} & \begin{tabular}{|l|}
-79.8988 \\
\end{tabular} & 0 & 0 & \begin{tabular}{|l|}
-79.8988 \\
\end{tabular} & 0 & 0 & 0 & 0 & 0 & 0 & 0 \\
\hline $\mathrm{U}_{3} \mathrm{O}_{8}$ & -23.770 & -23.770 & -23.770 & 0 & 0 & 0 & 0 & 842.085 & \begin{tabular}{|l|}
-842.0852 \\
\end{tabular} & 0 & 0 & \begin{tabular}{|l|}
0 \\
\end{tabular} & 0 & 0 & 0 & 0 & 0 & 0 & 0 \\
\hline $\mathrm{Y}_{2} \mathrm{O}_{3}$ & -12.910 & -12.910 & -12.910 & 0 & 0 & 1275.3196 & 0 & 225.808 & -225.8082 & 0 & 0 & 0 & 0 & 0 & 0 & 0 & 0 & 0 & 0 \\
\hline $\mathrm{ZnO}$ & 0.920 & 0.920 & 0.920 & 0 & 0 & 0 & 0 & \begin{tabular}{|l|}
81.369 \\
\end{tabular} & \begin{tabular}{|l|}
-81.3694 \\
\end{tabular} & 0 & 0 & 0 & 0 & 0 & 0 & 0 & 0 & 0 & 0 \\
\hline $\mathrm{ZrO}_{2}$ & 17.490 & 17.490 & 17.490 & 0 & 0 & 0 & 0 & 123.219 & \begin{tabular}{|l|}
-123.2188 \\
\end{tabular} & 0 & 0 & 0 & 0 & 0 & 0 & 0 & 0 & 0 & 0 \\
\hline PAR & \begin{tabular}{|c|}
-14.1058 \\
\end{tabular} & \begin{tabular}{|l|l|}
-13.8695 \\
\end{tabular} & \begin{tabular}{|l|}
-14.1991 \\
\end{tabular} & 0 & 0 & 210.9203 & 3.0 & 95.000 & \begin{tabular}{|l|}
-105 \\
\end{tabular} & 70 & -85 & -2 & -1 & -1 & -0.3 & -0.59 & -0.5 & -19.3 & 0 \\
\hline
\end{tabular}




\subsubsection{Test Case TC01}

The intent of test case TC01 is to show that activating thorium as a zero entry in the link between the measurements from the DWPF Laboratory and the inputs to PCCS introduces no changes to the output from the PCCS calculations without this zero entry. Thus, for this test case, the PCCS output is provided for a set values representing SME sample measurements without thorium values. This same set of PCCS output is then generated for the same set of SME sample measurements modified to have zero entries for thorium content.

Table A1 in Appendix A provides the measurements that are to be entered into PCCS to represent the SME samples before thorium entry is activated. This set of measurements is identified as TC01a. Table A2 in Appendix A provides the same set of measurements with zeros entered for the thorium content of these SME samples. These values are to be entered into PCCS after thorium has been activated in the link between the DWPF Laboratory information and PCCS. This set of measurements is identified as TC01b.

For both PCCS entries TC01a and TC01b, the PCCS output should be identical. The output that should be generated by PCCS for each of these two sets of SME sample measurements is provided in Table B1 of Appendix B. Specifically, the lines of output labeled as TC01 in this table should be used for comparisons between the output for TC01a and TC01b.

\subsubsection{Test Case TC02}

The intent of test case TC02 is to demonstrate that once a positive value for the concentration of thorium is entered into PCCS the constraints whose evaluations depend on thorium are appropriately modified. As indicated in the discussion above, the constraints involved are those associated with $\mathrm{B}, \mathrm{Li}$, and $\mathrm{Na}$ leaching (the durability model constraints) and the constraints associated with "Low Conserv" and "High Conserv" (the conservation of mass or sum of oxides constraints). To keep these comparisons simple yet comprehensive, the sample measurements for this test case will be the same as those for TC01 with the exception of the sample values for the thorium concentrations. The values for thorium will be selected so as to lead to an average of 1 weight percent elemental thorium for TC02. This is indicated in Table A3 of Appendix A.

Since the only change between the sample measurements of TC01 and those of TC02 is the thorium concentrations and since thorium activation leads to changes only in the constraints associated with $\mathrm{B}, \mathrm{Li}$, and $\mathrm{Na}$ leaching (the durability model constraints) and the constraints associated with "Low Conserv" and "High Conserv" (the conservation of mass or sum of oxides constraints), the PCCS output for TC02 should be identical to the output for TC01 for all of the other constraints. The PCCS output for TC02 is provided in Table B1 of Appendix B. Specifically, the lines of output labeled as TC02 in this table should be used to validate the PCCS output for TC02.

Please note that the derived values for $\Delta \mathrm{G}_{\mathrm{p}}$ increase slightly as one goes from TC01 to TC02 (i.e., the values go from -10.4607 to $-10.3779 \mathrm{kcal} / \mathrm{mole}$ ). This is a reflection of the positive coefficient for $\mathrm{ThO}_{2}$ in the durability models as seen in Table 2 . Also, please note that the derived value for sum of oxides increases from TC01 to TC02 (i.e., $97.3507 \mathrm{wt} \%$ to $98.4886 \mathrm{wt} \%$ ). The difference is 1.1379, the gravimetric factor for $\mathrm{ThO}_{2}$. 


\subsection{Conclusions and Recommendations}

The effort documented in this report indicates that no changes need to be made to the SME acceptability process (i.e., no modifications to [2] are needed) and no changes need to be made to the PCCS itself (i.e. the spreadsheet utilized by WSE for acceptability decisions does not require modification) in response to thorium becoming a reportable element for DWPF operations.

The inputs and results for the two test cases requested by WSE for use in confirming the successful activation of thorium as a reportable element for DWPF operations during the processing of SB6 are presented in this report. Appendix A provides the inputs for the two test cases, and Appendix B provides the results that should be generated by PCCS for each of these test cases. The arrangement of the output information in Appendix B is not identical to that provided in PCCS but all of the information critical for complete and successful comparisons is provided in that appendix.

While offering an independent path for confirming the successful activation of thorium as a reportable element for DWPF's processing of SB6, this approach does introduce the possibility for some round off errors, so care should be taken in comparing the test case results presented here to those generated by the modified link between the DWPF Laboratory information and PCCS. It is believed, however, that for most of the results provided in this report the values should be reproducible to five significant digits, when available, or to within $1 \%$.

\subsection{References}

[1] Peeler, DK and TB Edwards, "Impact of Thorium on PCCS Predictions within the Frit 418 -Sludge Batch 6 System,” SRNL-L3100-2010-00099, May 2010.

[2] Brown, KG, RL Postles, and TB Edwards, "SME Acceptability Determination for DWPF Process Control,” WSRC-TR-95-00364, Revision 5, September 2006.

[3] Bricker, JM, Technical Task Request: SME Acceptability and PCCS Test Cases Activation/Confirmation of Thorium,” HLW-DWPF-TTR-2010-00015, Revision 0, May 2010.

[4] Edwards, TB, “Task Technical and Quality Assurance Plan: Slurry Mix Evaporator Batch Acceptability and Test Cases for the Product Composition Control System with Thorium as a Reportable Element,” SRNL-RP-2010-01022, June 2010.

[5] Bricker, JM and JW Ray, "Proposed Test Cases for Activating Thorium in the Input Links to the Product Composition Control System (PCCS),” SRR-WSE-2010-00193, September 2010. 
Appendix A

Test Case Inputs 
Table A1 Inputs for Test Case TC01a

\begin{tabular}{|cr|rrrr|}
\hline & Average & \multicolumn{1}{|c}{ Sample 1 } & Sample 2 & Sample 3 & Sample 4 \\
Case ID & TC01a & TC01a-S1 & TC01a-S2 & TC01a-S3 & TC01a-S4 \\
\hline Solids & 42.6025 & 42.2400 & 43.0400 & 42.3200 & 42.8100 \\
Calcined Solids & 36.1275 & 35.8000 & 36.4400 & 35.7400 & 36.5300 \\
Spec. Gravity & 1.38925 & 1.3730 & 1.4250 & 1.3650 & 1.3940 \\
Al (wt\%) & 4.62050 & 4.6300 & 4.6390 & 4.6450 & 4.5680 \\
B (wt\%) & 1.53600 & 1.5170 & 1.5440 & 1.5510 & 1.5320 \\
Ba (wt\%) & & & & & \\
Ca (wt\%) & 0.36475 & 0.3520 & 0.3870 & 0.3690 & 0.3510 \\
Ce (wt\%) & & & & & \\
Cr (wt\%) & 0.02125 & 0.0210 & 0.0190 & 0.0220 & 0.0230 \\
Cs (wt\%) & & & & & \\
Cu (wt\%) & 0.01250 & 0.0100 & 0.0120 & 0.0150 & 0.0130 \\
Fe (wt\%) & 5.96800 & 5.9850 & 5.9730 & 6.0200 & 5.8940 \\
K (wt\%) & 0.05975 & -0.0380 & 0.0750 & -0.0980 & 0.3000 \\
La (wt\%) & & & & & \\
Li (wt\%) & 2.34900 & 2.3420 & 2.3400 & 2.3810 & 2.3330 \\
Mg (wt\%) & 0.20025 & 0.2040 & 0.1930 & 0.2040 & 0.2000 \\
Mn (wt\%) & 1.73975 & 1.8130 & 1.7990 & 1.6710 & 1.6760 \\
Mo (wt\%) & & & & & \\
Na (wt\%) & 10.36825 & 10.5670 & 10.3200 & 10.2870 & 10.2990 \\
Nd (wt\%) & & & & & \\
Ni (wt\%) & 0.68950 & 0.7010 & 0.6550 & 0.7060 & 0.6960 \\
Pb (wt\%) & & & & & \\
Si (wt\%) & 23.32900 & 23.5320 & 23.3570 & 23.4320 & 22.9950 \\
Th (wt\%) & & & & & \\
Ti (wt\%) & 0.03775 & 0.1330 & 0.0070 & 0.0070 & 0.0040 \\
U (wt\%) & 1.53900 & 1.5850 & 1.5580 & 1.5050 & 1.5080 \\
Y (wt\%) & & & & & \\
Zn (wt\%) & & & & & \\
Zr (wt\%) & 0.09475 & 0.0980 & 0.0930 & 0.0950 & 0.0930 \\
Cl (ppm) & 536.5000 & 550.0000 & 525.0000 & 532.0000 & 539.0000 \\
F (ppm) & 536.5000 & 550.0000 & 525.0000 & 532.0000 & 539.0000 \\
HCOO (ppm) & 35246.0000 & 35657.0000 & 33443.0000 & 35054.0000 & 36830.0000 \\
NO2 (ppm) & 536.5000 & 550.0000 & 525.0000 & 532.0000 & 539.0000 \\
NO3 (ppm) & 14179.0000 & 14039.0000 & 13640.0000 & 13808.0000 & 15229.0000 \\
PO4 (ppm) & 536.5000 & 550.0000 & 525.0000 & 532.0000 & 539.0000 \\
SO4 (ppm) & 1024.7500 & 1051.0000 & 992.0000 & 1054.0000 & 1002.0000 \\
TOC (ppm) & 3655.0000 & 14620.0000 & 0.0000 & 0.0000 & 0.0000 \\
\hline
\end{tabular}


Table A2. Inputs for Test Case TC01b

\begin{tabular}{|c|c|c|c|c|c|}
\hline Case ID & $\begin{array}{c}\text { Average } \\
\text { TC01b }\end{array}$ & $\begin{array}{c}\text { Sample } 1 \\
\text { TC01b-S1 }\end{array}$ & $\begin{array}{c}\text { Sample } 2 \\
\text { TC01b-S2 } \\
\end{array}$ & $\begin{array}{c}\text { Sample } 3 \\
\text { TC01b-S3 }\end{array}$ & $\begin{array}{c}\text { Sample } 4 \\
\text { TC01b-S4 }\end{array}$ \\
\hline Solids & 42.6025 & 42.2400 & 43.0400 & 42.3200 & 42.8100 \\
\hline Calcined Solids & 36.1275 & 35.8000 & 36.4400 & 35.7400 & 36.5300 \\
\hline Spec. Gravity & 1.38925 & 1.3730 & 1.4250 & 1.3650 & 1.3940 \\
\hline $\mathrm{Al}(\mathrm{wt} \%)$ & 4.62050 & 4.6300 & 4.6390 & 4.6450 & 4.5680 \\
\hline $\begin{array}{c}\mathrm{B}(\mathrm{wt} \%) \\
\mathrm{Ba}(\mathrm{wt} \%)\end{array}$ & 1.53600 & 1.5170 & 1.5440 & 1.5510 & 1.5320 \\
\hline $\begin{array}{l}\text { Ca (wt\%) } \\
\text { Ce (wt\%) }\end{array}$ & 0.36475 & 0.3520 & 0.3870 & 0.3690 & 0.3510 \\
\hline $\begin{array}{l}\text { Cr (wt\%) } \\
\text { Cs (wt\%) }\end{array}$ & 0.02125 & 0.0210 & 0.0190 & 0.0220 & 0.0230 \\
\hline $\mathrm{Cu}(\mathrm{wt} \%)$ & 0.01250 & 0.0100 & 0.0120 & 0.0150 & 0.0130 \\
\hline $\mathrm{Fe}(\mathrm{wt} \%)$ & 5.96800 & 5.9850 & 5.9730 & 6.0200 & 5.8940 \\
\hline $\begin{array}{l}\mathrm{K}(\mathrm{wt} \%) \\
\mathrm{La}(\mathrm{wt} \%)\end{array}$ & 0.05975 & -0.0380 & 0.0750 & -0.0980 & 0.3000 \\
\hline Li (wt\%) & 2.34900 & 2.3420 & 2.3400 & 2.3810 & 2.3330 \\
\hline Mg (wt\%) & 0.20025 & 0.2040 & 0.1930 & 0.2040 & 0.2000 \\
\hline $\begin{array}{l}\text { Mn (wt\%) } \\
\text { Mo (wt\%) }\end{array}$ & 1.73975 & 1.8130 & 1.7990 & 1.6710 & 1.6760 \\
\hline $\begin{array}{l}\mathrm{Na}(\mathrm{wt} \%) \\
\mathrm{Nd}(\mathrm{wt} \%)\end{array}$ & 10.36825 & 10.5670 & 10.3200 & 10.2870 & 10.2990 \\
\hline $\begin{array}{l}\mathrm{Ni}(\mathrm{wt} \%) \\
\mathrm{Pb}(\mathrm{wt} \%)\end{array}$ & 0.68950 & 0.7010 & 0.6550 & 0.7060 & 0.6960 \\
\hline Si (wt\%) & 23.32900 & 23.5320 & 23.3570 & 23.4320 & 22.9950 \\
\hline Th (wt\%) & 0 & 0 & 0 & 0 & 0 \\
\hline Ti (wt\%) & 0.03775 & 0.1330 & 0.0070 & 0.0070 & 0.0040 \\
\hline $\begin{array}{c}\mathrm{U}(\mathrm{wt} \%) \\
\mathrm{Y}(\mathrm{wt} \%) \\
\mathrm{Zn}(\mathrm{wt} \%)\end{array}$ & 1.53900 & 1.5850 & 1.5580 & 1.5050 & 1.5080 \\
\hline Zr (wt\%) & 0.09475 & 0.0980 & 0.0930 & 0.0950 & 0.0930 \\
\hline $\mathrm{Cl}$ (ppm) & 536.5000 & 550.0000 & 525.0000 & 532.0000 & 539.0000 \\
\hline F (ppm) & 536.5000 & 550.0000 & 525.0000 & 532.0000 & 539.0000 \\
\hline HCOO (ppm) & 35246.0000 & 35657.0000 & 33443.0000 & 35054.0000 & 36830.0000 \\
\hline NO2 (ppm) & 536.5000 & 550.0000 & 525.0000 & 532.0000 & 539.0000 \\
\hline NO3 (ppm) & 14179.0000 & 14039.0000 & 13640.0000 & 13808.0000 & 15229.0000 \\
\hline PO4 (ppm) & 536.5000 & 550.0000 & 525.0000 & 532.0000 & 539.0000 \\
\hline SO4 (ppm) & 1024.7500 & 1051.0000 & 992.0000 & 1054.0000 & 1002.0000 \\
\hline TOC (ppm) & 3655.0000 & 14620.0000 & 0.0000 & 0.0000 & 0.0000 \\
\hline
\end{tabular}


Table A3. Inputs for Test Case TC02

\begin{tabular}{|c|c|c|c|c|c|}
\hline Case ID & $\begin{array}{c}\text { Average } \\
\text { TC02 }\end{array}$ & $\begin{array}{l}\text { Sample } 1 \\
\text { TC02-S1 }\end{array}$ & $\begin{array}{l}\text { Sample } 2 \\
\text { TC02-S2 }\end{array}$ & $\begin{array}{l}\text { Sample } 3 \\
\text { TC02-S3 }\end{array}$ & $\begin{array}{l}\text { Sample } 4 \\
\text { TC02-S4 }\end{array}$ \\
\hline Solids & 42.6025 & 42.2400 & 43.0400 & 42.3200 & 42.8100 \\
\hline Calcined Solids & 36.1275 & 35.8000 & 36.4400 & 35.7400 & 36.5300 \\
\hline Spec. Gravity & 1.38925 & 1.3730 & 1.4250 & 1.3650 & 1.3940 \\
\hline $\mathrm{Al}(\mathrm{wt} \%)$ & 4.62050 & 4.6300 & 4.6390 & 4.6450 & 4.5680 \\
\hline $\begin{array}{c}\mathrm{B}(w \mathrm{t} \%) \\
\mathrm{Ba}(\mathrm{wt} \%)\end{array}$ & 1.53600 & 1.5170 & 1.5440 & 1.5510 & 1.5320 \\
\hline $\begin{array}{l}\mathrm{Ca}(\mathrm{wt} \%) \\
\mathrm{Ce}(\mathrm{wt} \%)\end{array}$ & 0.36475 & 0.3520 & 0.3870 & 0.3690 & 0.3510 \\
\hline $\begin{array}{l}\text { Cr (wt\%) } \\
\text { Cs (wt\%) }\end{array}$ & 0.02125 & 0.0210 & 0.0190 & 0.0220 & 0.0230 \\
\hline $\mathrm{Cu}(\mathrm{wt} \%)$ & 0.01250 & 0.0100 & 0.0120 & 0.0150 & 0.0130 \\
\hline $\mathrm{Fe}(\mathrm{wt} \%)$ & 5.96800 & 5.9850 & 5.9730 & 6.0200 & 5.8940 \\
\hline $\begin{array}{l}\mathrm{K}(w \mathrm{t} \%) \\
\mathrm{La}(w \mathrm{t} \%)\end{array}$ & 0.05975 & -0.0380 & 0.0750 & -0.0980 & 0.3000 \\
\hline $\mathrm{Li}(\mathrm{wt} \%)$ & 2.34900 & 2.3420 & 2.3400 & 2.3810 & 2.3330 \\
\hline $\mathrm{Mg}(\mathrm{wt} \%)$ & 0.20025 & 0.2040 & 0.1930 & 0.2040 & 0.2000 \\
\hline $\begin{array}{l}\text { Mn (wt\%) } \\
\text { Mo (wt\%) }\end{array}$ & 1.73975 & 1.8130 & 1.7990 & 1.6710 & 1.6760 \\
\hline $\begin{array}{l}\mathrm{Na}(\mathrm{wt} \%) \\
\mathrm{Nd}(\mathrm{wt} \%)\end{array}$ & 10.36825 & 10.5670 & 10.3200 & 10.2870 & 10.2990 \\
\hline $\begin{array}{l}\mathrm{Ni}(\mathrm{wt} \%) \\
\mathrm{Pb}(\mathrm{wt} \%)\end{array}$ & 0.68950 & 0.7010 & 0.6550 & 0.7060 & 0.6960 \\
\hline Si (wt\%) & 23.32900 & 23.5320 & 23.3570 & 23.4320 & 22.9950 \\
\hline Th (wt\%) & 1.00000 & 0.9000 & 1.0000 & 1.1000 & 1.0000 \\
\hline $\mathrm{Ti}$ (wt\%) & 0.03775 & 0.1330 & 0.0070 & 0.0070 & 0.0040 \\
\hline $\begin{array}{c}\mathrm{U}(w t \%) \\
Y(w t \%) \\
Z n(w t \%)\end{array}$ & 1.53900 & 1.5850 & 1.5580 & 1.5050 & 1.5080 \\
\hline $\mathrm{Zr}(\mathrm{wt} \%)$ & 0.09475 & 0.0980 & 0.0930 & 0.0950 & 0.0930 \\
\hline $\mathrm{Cl}$ (ppm) & 536.5000 & 550.0000 & 525.0000 & 532.0000 & 539.0000 \\
\hline F (ppm) & 536.5000 & 550.0000 & 525.0000 & 532.0000 & 539.0000 \\
\hline HCOO (ppm) & 35246.0000 & 35657.0000 & 33443.0000 & 35054.0000 & 36830.0000 \\
\hline NO2 (ppm) & 536.5000 & 550.0000 & 525.0000 & 532.0000 & 539.0000 \\
\hline NO3 (ppm) & 14179.0000 & 14039.0000 & 13640.0000 & 13808.0000 & 15229.0000 \\
\hline PO4 (ppm) & 536.5000 & 550.0000 & 525.0000 & 532.0000 & 539.0000 \\
\hline SO4 (ppm) & 1024.7500 & 1051.0000 & 992.0000 & 1054.0000 & 1002.0000 \\
\hline TOC (ppm) & 3655.0000 & 14620.0000 & 0.0000 & 0.0000 & 0.0000 \\
\hline
\end{tabular}


SRNL-STI-2010-00557

Revision 0

\section{Appendix B}

Test Case Results 


\section{Table B1. Results for Test Cases}

\begin{tabular}{|c|c|c|c|}
\hline Test & \multicolumn{3}{|c|}{$\Delta \mathrm{G}_{\mathrm{p}}$ PAR Value (kcal/mole) } \\
\hline Case ID & Boron & Lithium & Sodium \\
\hline TC01 & -14.1058 & -13.8695 & -14.1991 \\
\hline TC02 & -14.1058 & -13.8695 & -14.1991 \\
\hline
\end{tabular}

\begin{tabular}{|c|c|c|c|c|c|c|}
\hline Test & \multicolumn{2}{|c|}{$\Delta \mathrm{G}_{\mathrm{p}} \mathrm{MAR}$ Value (kcal/mole) } & \multicolumn{3}{c|}{$\Delta \mathrm{G}_{\mathrm{p}}$ Derived Value (kcal/mole) } \\
\hline Case ID & Boron & Lithium & Sodium & Boron & \multicolumn{1}{c|}{ Lithium } & \multicolumn{1}{c|}{ Sodium } \\
\hline TC01 & -13.7200 & -13.4837 & -13.8133 & -10.4607 & -10.4607 & -10.4607 \\
\hline TC02 & -13.7200 & -13.4837 & -13.8133 & -10.3779 & -10.3779 & -10.3779 \\
\hline
\end{tabular}

\begin{tabular}{|c|r|r|r|r|r|r|r|}
\hline Test & \multicolumn{3}{|c|}{$\Delta \mathrm{G}_{\mathrm{p}}$ MAR Difference (kcal/mole) } & \multirow{2}{*}{ Constraints } & \multicolumn{3}{|c|}{ Property Values (g/L) } \\
\cline { 1 - 3 } \cline { 7 - 8 } Case ID & Boron & Lithium & Sodium & Met & Boron & Lithium & Sodium \\
\hline TC01 & 3.2592 & 3.0229 & 3.3525 & Yes & 0.986 & 0.977 & 0.972 \\
\hline TC02 & 3.3421 & 3.1058 & 3.4354 & Yes & 0.953 & 0.950 & 0.941 \\
\hline
\end{tabular}

\begin{tabular}{|c|c|c|c|c|c|c|c|c|}
\hline & Liquidus & High & Low & Homogeneity & & & Low & High \\
\hline Test & Temp $\left(\mathrm{T}_{\mathrm{L}}\right)$ & Viscosity & Viscosity & PAR & Sum of Oxides PAR & Frit & Frit \\
\hline Case ID & PAR Value & PAR Value & PAR Value & Value & Low & High & PAR Value & PAR Value \\
\hline TC01 & 1032.4 & 0 & 0 & 210.9203 & 95 & -105 & 70 & -85 \\
\hline TC02 & 1032.4 & 0 & 0 & 210.9203 & 95 & -105 & 70 & -85 \\
\hline Units & ${ }^{\circ} \mathrm{C}$ & unitless & unitless & wt $\%$ & wt $\%$ & wt $\%$ & wt $\%$ & wt $\%$ \\
\hline
\end{tabular}

\begin{tabular}{|c|c|c|c|c|c|c|c|c|}
\hline & Liquidus & High & Low & Homogeneity & & & Low & High \\
\hline Test & Temp $\left(\mathrm{T}_{\mathrm{L}}\right)$ & Viscosity & Viscosity & MAR & Sum of Oxides MAR & Frit & Frit \\
\hline Case ID & MAR Value & MAR Value & MAR Value & Value & Low & High & MAR Value & MAR Value \\
\hline TC01 & 1008.908 & 0.01187 & 0.025807 & 219.5137 & 95 & -105 & 73.1656 & -81.8344 \\
\hline TC02 & 1008.908 & 0.01187 & 0.025807 & 219.5137 & 95 & -105 & 73.1656 & -81.8344 \\
\hline Units & ${ }^{\circ} \mathrm{C}$ & unitless & unitless & wt $\%$ & wt $\%$ & wt $\%$ & wt $\%$ & wt $\%$ \\
\hline
\end{tabular}

\begin{tabular}{|c|c|c|c|c|c|c|c|c|}
\hline & Liquidus & High & Low & & Sum of Oxides & Low & High \\
\hline Test & Temp $\left(\mathrm{T}_{\mathrm{L}}\right)$ & Viscosity & Viscosity & Homogeneity & Derived Value & Frit & Frit \\
\hline Case ID & $\begin{array}{c}\text { Derived } \\
\text { Value }\end{array}$ & $\begin{array}{c}\text { Derived } \\
\text { Value }\end{array}$ & $\begin{array}{c}\text { Derived } \\
\text { Value }\end{array}$ & $\begin{array}{c}\text { Derived } \\
\text { Value }\end{array}$ & Low & High & $\begin{array}{c}\text { Derived } \\
\text { Value }\end{array}$ & $\begin{array}{c}\text { Derived } \\
\text { Value }\end{array}$ \\
\hline TC01 & 853.428 & 0.1437 & 0.1942 & 218.9730 & 97.3507 & -97.3507 & 73.9590 & -73.9590 \\
\hline TC02 & 853.428 & 0.1437 & 0.1942 & 218.9730 & 98.4886 & -98.4886 & 73.9590 & -73.9590 \\
\hline Units & ${ }^{\circ} \mathrm{C}$ & unitless & unitless & wt\% & wt $\%$ & wt\% & wt\% & wt\% \\
\hline
\end{tabular}

\begin{tabular}{|c|c|c|c|c|c|c|c|c|}
\hline & Liquidus & High & Low & & \multicolumn{2}{c|}{ Sum of Oxides } & Low & High \\
\hline Test & Temp $\left(\mathrm{T}_{\mathrm{L}}\right.$ ) & Viscosity & Viscosity & Homogeneity & \multicolumn{2}{|c|}{ MAR Diff } & Frit & Frit \\
\hline Case ID & MAR Diff & MAR Diff & MAR Diff & MAR Diff & Low & High & MAR Diff & MAR Diff \\
\hline TC01 & 155.48 & 0.1319 & 0.1683 & -0.5407 & 2.3507 & 7.6493 & 0.7934 & 7.8753 \\
\hline TC02 & 155.48 & 0.1319 & 0.1683 & -0.5407 & 3.4886 & 6.5114 & 0.7934 & 7.8753 \\
\hline Units & ${ }^{0} \mathrm{C}$ & unitless & unitless & wt $\%$ & wt $\%$ & wt $\%$ & wt $\%$ & wt $\%$ \\
\hline
\end{tabular}

\section{Property Values}

\begin{tabular}{|c|c|c|c|c|c|c|c|c|}
\hline & Liquidus & High & Low & & \multicolumn{2}{c|}{ Sum of Oxides } & Low & High \\
\hline Test & Temp $\left(\mathrm{T}_{\mathrm{L}}\right.$ ) & Viscosity & Viscosity & Homogeneity & \multicolumn{2}{|c|}{ Values } & Frit & Frit \\
\hline Case ID & Prediction & Pred Value & Pred Value & Value & Low & High & Value & Value \\
\hline TC01 & 853.428 & 53.704 & 53.704 & 218.973 & 97.3507 & 97.3507 & 73.959 & 73.959 \\
\hline TC02 & 853.428 & 53.704 & 53.704 & 218.973 & 98.4886 & 98.4886 & 73.959 & 73.959 \\
\hline Units & ${ }^{\circ} \mathrm{C}$ & Poise & Poise & wt $\%$ & wt $\%$ & wt $\%$ & wt $\%$ & wt $\%$ \\
\hline
\end{tabular}


Table B1. Results for Test Cases (continued)

MAR Values

\begin{tabular}{|c|c|c|c|c|c|c|c|c|c|c|c|}
\hline & $\mathrm{Al}_{2} \mathrm{O}_{3}$ & $\mathrm{Al}_{2} \mathrm{O}_{3}{ }^{\mathrm{a}}$ & $\mathrm{Al}_{2} \mathrm{O}_{3}{ }^{\mathrm{b}}$ & $\mathrm{TiO}_{2}$ & $\mathrm{NaCl}$ & $\mathrm{NaF}$ & $\mathrm{Cr}_{2} \mathrm{O}_{3}$ & $\mathrm{Na}_{2} \mathrm{SO}_{4}$ & $\mathrm{Cu}$ & $\mathrm{R}_{2} \mathrm{O}$ & \\
\hline Test & $\mathrm{wt} \%$ & $\mathrm{wt} \%$ & $\mathrm{wt} \%$ & $\mathrm{wt} \%$ & $\mathrm{wt} \%$ & $\mathrm{wt} \%$ & $\mathrm{wt} \%$ & $\mathrm{wt} \%$ & $\mathrm{wt} \%$ & wt\% & Units \\
\hline $\begin{array}{c}\text { Case } \\
\text { ID }\end{array}$ & 3 & 4 & 4.43 & -2 & -1 & -1 & -0.3 & -0.59 & -0.5 & -19.3 & $\begin{array}{l}\text { PAR } \\
\text { Value }\end{array}$ \\
\hline TC01 & 3.3831 & 4.3831 & 4.8131 & -1.9835 & -1 & -1 & -0.2730 & -0.59 & -0.4875 & -18.5999 & \\
\hline TC02 & 3.3831 & 4.3831 & 4.8131 & -1.9835 & -1 & -1 & -0.2730 & -0.59 & -0.4875 & -18.5999 & \\
\hline
\end{tabular}

\section{Derived Values}

\begin{tabular}{|c|c|c|c|c|c|c|c|c|c|c|c|}
\hline Test & $\mathrm{Al}_{2} \mathrm{O}_{3}$ & $\mathrm{Al}_{2} \mathrm{O}_{3}$ & $\mathrm{Al}_{2} \mathrm{O}_{3}$ & $\mathrm{TiO}_{2}$ & $\mathrm{NaCl}$ & $\mathrm{NaF}$ & $\mathrm{Cr}_{2} \mathrm{O}_{3}$ & $\mathrm{Na}_{2} \mathrm{SO}_{4}$ & $\mathrm{Cu}$ & $\mathrm{R}_{2} \mathrm{O}$ & \\
\hline $\begin{array}{c}\text { Case } \\
\text { ID }\end{array}$ & wt\% & wt\% & wt\% & wt\% & wt\% & wt\% & wt\% & wt\% & wt\% & wt\% & Units \\
\hline TC01 & 8.7304 & 8.7304 & 8.7304 & -0.0630 & -0.2448 & -0.3282 & -0.0311 & -0.4195 & -0.0125 & -19.1055 & \\
\hline TC02 & 8.7304 & 8.7304 & 8.7304 & -0.0630 & -0.2448 & -0.3282 & -0.0311 & -0.4195 & -0.0125 & -19.1055 & \\
\hline
\end{tabular}

MAR Differences

\begin{tabular}{|c|c|c|c|c|c|c|c|c|c|c|}
\hline Test & $\mathrm{Al}_{2} \mathrm{O}_{3}$ & $\mathrm{Al}_{2} \mathrm{O}_{3}$ & $\mathrm{Al}_{2} \mathrm{O}_{3}$ & $\mathrm{TiO}_{2}$ & $\mathrm{NaCl}$ & $\mathrm{NaF}$ & $\mathrm{Cr}_{2} \mathrm{O}_{3}$ & $\mathrm{Na}_{2} \mathrm{SO}_{4}$ & $\mathrm{Cu}$ & $\mathrm{R}_{2} \mathrm{O}$ \\
\hline $\begin{array}{c}\text { Case } \\
\text { ID }\end{array}$ & $\mathrm{wt} \%$ & $\mathrm{wt} \%$ & $\mathrm{wt} \%$ & $\mathrm{wt} \%$ & $\mathrm{wt} \%$ & $\mathrm{wt} \%$ & $\mathrm{wt} \%$ & $\mathrm{wt} \%$ & $\mathrm{wt} \%$ & $\mathrm{wt} \%$ \\
\hline TC01 & 5.3473 & 4.3473 & 3.9173 & 1.9205 & 0.7552 & 0.6718 & 0.2420 & 0.1705 & 0.4750 & -0.5056 \\
\hline TC02 & 5.3473 & 4.3473 & 3.9173 & 1.9205 & 0.7552 & 0.6718 & 0.2420 & 0.1705 & 0.4750 & -0.5056 \\
\hline
\end{tabular}

Property Values

\begin{tabular}{|c|c|c|c|c|c|c|c|c|c|c|}
\hline Test & $\mathrm{Al}_{2} \mathrm{O}_{3}$ & $\mathrm{Al}_{2} \mathrm{O}_{3}$ & $\mathrm{Al}_{2} \mathrm{O}_{3}$ & $\mathrm{TiO}_{2}$ & $\mathrm{NaCl}$ & $\mathrm{NaF}$ & $\mathrm{Cr}_{2} \mathrm{O}_{3}$ & $\mathrm{Na}_{2} \mathrm{SO}_{4}$ & $\mathrm{Cu}$ & $\left(\mathrm{R}_{2} \mathrm{O}\right)$ \\
\hline $\begin{array}{c}\text { Case } \\
\text { ID }\end{array}$ & $\mathrm{wt} \%$ & $\mathrm{wt} \%$ & $\mathrm{wt} \%$ & $\mathrm{wt} \%$ & $\mathrm{wt} \%$ & $\mathrm{wt} \%$ & $\mathrm{wt} \%$ & wt\% & wt\% & wt\% \\
\hline TC01 & 8.7304 & 8.7304 & 8.7304 & 0.0630 & 0.2448 & 0.3282 & 0.0311 & 0.4195 & 0.0125 & 19.1055 \\
\hline TC02 & 8.7304 & 8.7304 & 8.7304 & 0.0630 & 0.2448 & 0.3282 & 0.0311 & 0.4195 & 0.0125 & 19.1055 \\
\hline
\end{tabular}

Nepheline Constraint
\begin{tabular}{|c|c|c|c|c|c|}
\hline $\begin{array}{c}\text { Test } \\
\text { Case ID }\end{array}$ & PAR & MAR & $\begin{array}{c}\text { Derived } \\
\text { Value }\end{array}$ & $\begin{array}{c}\text { MAR } \\
\text { Difference }\end{array}$ & $\begin{array}{c}\text { Nepheline } \\
\text { Value }\end{array}$ \\
\hline TC01 & 0 & 0.67776 & 4.8867 & 4.2089 & 0.687 \\
\hline TC02 & 0 & 0.67776 & 4.8867 & 4.2089 & 0.687 \\
\hline Units & unitless & unitless & unitless & unitless & unitless \\
\hline
\end{tabular}

a This constraint on $\mathrm{Al}_{2} \mathrm{O}_{3}$ is not an explicit PCCS output; the constraint is used as an alternate to the homogeneity MAR evaluation.

${ }^{\mathrm{b}}$ This constraint on $\mathrm{Al}_{2} \mathrm{O}_{3}$ is not an explicit PCCS output; the constraint is used as an alternate to the low frit MAR evaluation. 
SRNL-STI-2010-00557

Revision 0

\section{Appendix C}

\section{E-Mail Modifying Scope of Work for this Task}

Email for Tommy Edwards

\begin{tabular}{|c|c|c|}
\hline & $\begin{array}{c}\text { Deletion Request: HWW-DWPF-TTR-2010-00015. "SME. } \\
\text { PCCS Test Cases - ActivationCorfimmation of Tharium" } \\
\text { Tommy Edwards, Connie Herma n, John } \\
\text { bnathan Bricker to: Occhip int, Terri Fellinger, Aaron Staub, } \\
\text { Herbert Elder, Jeff Ray }\end{array}$ & 10/08/2010 01:56 PM \\
\hline Histary: & This message has been replisd to. & \\
\hline
\end{tabular}

Tommy,

Per our discussion earlier this week, please delete the prior additional request to

"...generate a white paper providing a statistica/ method for estimating thorium concentrations based on the established analysis of iron...

from the scope of work captured in HLW-DWPF-TTR-2010-00015. I suppose it ca n also be removed from the Test Case Report (SRNL-STI-2010-00557). I apologize for any confusion this may have caused. This was certainly a bit of a "knee-jerk" reaction on our part.

Thanks,

Jonathan Bricker

DWPF-Engineering

8.7164 


\section{Distribution:}

\begin{tabular}{|c|c|}
\hline Name: & Location \\
\hline Sharon Marra & 773-A \\
\hline Connie Herman & 999-W \\
\hline Allan Barnes & 999-W \\
\hline Patricia Lee & $703-41 \mathrm{~A}$ \\
\hline Gene Shine & $703-41 \mathrm{~A}$ \\
\hline Michael Stone & 999-W \\
\hline David Peeler & 999-W \\
\hline Tommy Edwards & 999-W \\
\hline Amanda Billings & 999-W \\
\hline Kevin Fox & 999-W \\
\hline Fabienne Johnson & 999-W \\
\hline Charles Crawford & $773-42 \mathrm{~A}$ \\
\hline John Occhipinti & $704-S$ \\
\hline Jonathan Bricker & $704-27 \mathrm{~S}$ \\
\hline John Iaukea & 704-30S \\
\hline Aaron Staub & $704-27 \mathrm{~S}$ \\
\hline Jeff Ray & $704-S$ \\
\hline Robert Hinds & $704-S$ \\
\hline Terri Fellinger & $704-26 S$ \\
\hline Amanda Shafer & $704-27 \mathrm{~S}$ \\
\hline Mason Clark & $704-27 \mathrm{~S}$ \\
\hline Helen Pittman & $704-27 \mathrm{~S}$ \\
\hline Hank Elder & $704-24 S$ \\
\hline Bill Holtzscheiter & $704-15 S$ \\
\hline Pat Vaughan & $773-41 \mathrm{~A}$ \\
\hline
\end{tabular}

